OPEN ACCESS

Edited by:

Xunhua Zhang,

Qingdao Institute of Marine Geology,

China

Reviewed by:

Chuansong $\mathrm{He}$,

Institute of Geophysics, China

Xin Liu,

Ocean University of China, China

*Correspondence:

Song Huang

huangsong@mail.iggcas.ac.cn

Specialty section:

This article was submitted to Solid Earth Geophysics,

a section of the journal

Frontiers in Earth Science

Received: 04 November 2021

Accepted: 21 December 2021

Published: 10 January 2022

Citation:

Deng $Y$, Huang $S, W U X$ and $L i M$ (2022) Research Progress on Cenozoic Volcano Genesis and Fluid Action in Northeast China. Front. Earth Sci. 9:808914. doi: 10.3389/feart.2021.808914

\section{Research Progress on Cenozoic Volcano Genesis and Fluid Action in Northeast China}

\author{
Yufeng Deng ${ }^{1,2,3}$, Song Huang ${ }^{1,2 *}$, Xueshan $W u^{1,2,3}$ and Min $L i^{1,2,3}$ \\ ${ }^{1}$ Key Laboratory of Petroleum Resources Research, Institute of Geology and Geophysics, Chinese Academy of Sciences, Beijing, \\ China, ${ }^{2}$ Innovation Academy for Earth Science, Chinese Academy of Sciences, Beijing, China, ${ }^{3}$ College of Earth and Planetary \\ Sciences, University of Chinese Academy of Sciences, Beijing, China
}

The tectonic evolution of northeast China is closely related to the subduction of the Pacific plate. The dehydration of the slab subduction process produces metasomatic agents that have important effects on the physical and chemical properties of the mantle wedge, including the decrease of seismic wave velocity and the increase of Poisson's ratio and electrical conductivity. In order to investigate the tectonic evolution and fluid action of northeast China, this paper compares the previous seismic and electromagnetic imaging results of northeast China and explores the relationship between the genesis of Cenozoic volcanoes and fluid action in northeast China through rheological analysis. The results show that the western Pacific plate subducted into the mantle transition zone beneath northeast China, and sustained dehydration occurred. The upward migration of these released water caused partial melting at the base of the upper mantle. Some of the upwelling streams pierced the weak tectonic boundary under the buoyancy effect, which finally formed the large-scale Cenozoic volcanic events in northeast China.

Keywords: volcano genesis, fluid, stagnant slab, seismic velocity, electrical conductivity

\section{INTRODUCTION}

In northeast China, the northern margin of the Songliao Basin and its eastern and western flanks have developed many volcanoes, such as Changbaishan volcano, Longgang volcano, Jingpohu volcano, Abaga volcano, Halaha volcano, Wudalianchi volcano, and Nuominhe volcano. The formation mechanism of these volcanoes involves the core scientific problem of multi-layer interaction of the Earth system in Northeast Asia. Furthermore, it is the key to advancing the solution of major geoscientific issues related to the deep subduction of plates.

To investigate the volcano genesis of northeast China, many researchers have done much work and put forward some hypotheses about the formation mechanism of these volcanoes. Turcotte and Schubert (1982) suggested that the volcanoes in northeast China are hotspot volcanism formed by magma in the tail of the mantle column. (Miyashiro, 1986). proposed a "hot region" hypothesis, suggesting that the "hot region" transported beneath northeast China provided the source of volcanic activities. Tatsumi et al. (1990) explained the volcano genesis of northeast China using large-scale material injection into the crust from the Asthenosphere. Iwamori (1992) suggested that the deep primitive mantle became a molten "wet region" due to the lowering of solidus temperature by adding fluids. Buoyancy transported the partially molten mantle upward, causing crustal melting and volcanic activity near the upwelling center. Tatsumi and Eggins (1995) suggested that the thermal 
upwelling of mantle peridotite separated from the stagnant slab lowered the solidus temperature of the shallow mantle and eventually triggered volcanic activity.

With more and more geophysical imaging work in northeast China, low-velocity and high-conductivity anomalies have been found in the upper mantle beneath the volcanoes in northeast China, which are located above the Pacific plate where the mantle transition has stalled. These results suggested that these volcanoes are back-arc intraplate volcanos closely linked to the subduction process of the Pacific plate (Ichiki et al., 2001; Zhao, 2004). Meanwhile, arc magmatism is usually due to corner flows in the mantle wedge and dehydration reactions during subduction. The rocks and minerals in the subduction zone contain some amount of water. During subduction, temperature and pressure changes, hydrous minerals decompose, and water is released by dehydration of the subducted crust, leading to partial melting of the subducted crust itself or the overlying mantle wedge. These processes may have led to large-scale upwelling of material from the northeast China Asthenosphere, resulting in intraplate volcanism (Zhao et al., 2011). In addition, the numerical simulation result of (Yang and Faccenda, 2020) also indicates that the Cenozoic volcanism in northeast China is the result of the interaction between the subducting Pacific slab and the hydrous mantle transition zone.

The water released during plate subduction will be metasomatic with the overlying mantle wedge minerals. The agents for mantle metasomatism will have important effects on the physical and chemical properties of the mantle wedge, including the decrease of seismic wave velocity and the increase of Poisson's ratio and conductivity (Zheng et al., 2016). To this end, this paper explores the relationship between volcano genesis and fluid action in northeast China by sorting out previous seismic and electromagnetic imaging results and extracting information on geological processes and fluid action reflected by geophysical imaging results through rheological analysis.

\section{REGIONAL GEOLOGICAL BACKGROUND}

Northeast China locates on the eastern edge of the Central Asian Orogenic Belt, surrounded by the Siberian plate in the north, the North China plate in the south, and the West Pacific plate in the east. Its internal geology is intricate and complex, forming a tectonic framework of mainly stretching and local extrusion. The general geomorphology shows a geotectonic pattern of basins and mountains arranged in an interlocking way along the northeast (Li et al., 2018).

It is generally accepted that northeast China has undergone two periods of tectonic evolution. During the Paleozoic, the tectonic evolution was mainly influenced by the Paleo-Asian Ocean between the Siberian Craton and the North China Craton; Since the Late Mesozoic, the East Asian continent has transitioned from the Paleo-Asian Ocean tectonic domain to the continental margin, and the lithosphere underwent multiple periods of extensional deformation. During this period, the Pacific plate subduction was the main factor controlling the tectonic evolution of the region. In the Early Cretaceous, the
North China Craton was destroyed by the subduction of the Paleo-Pacific plate (should have already collapsed into the lower mantle). And the present stagnant Pacific slab in the mantle transition zone has contributed to the Cenozoic destruction of the East Asian continental lithosphere. (Zhou et al., 2014; Sun et al., 2015; Zhou and Li, 2017; Liu X et al., 2017; Liu Y et al., 2017). Volcanoes in northeast China are distributed linearly around the Songliao Basin. The main distribution zones are the MishanDunhua Fault, the Yilan-Yitong Fault, the Heihe-Hegenshan Suture Zone, the Xiao Hinggan Mountains, and the Greater Khingan Range. Moreover, the confirmed Cenozoic volcanoes are the Changbaishan volcano, the Longgang volcano, the Jingpohu volcano, the Wudalianchi volcano, the Abaga volcano, Nuominhe volcano, among others (Figure 1).

\section{SEISMIC IMAGING RESULTS}

Global and regional seismic tomography results (Fukao et al., 1992; Zhao, 2004; Zhao et al., 2011; Fukao and Obayashi, 2013; Chen et al., 2017; Zhao, 2021) generally show that the northwest Pacific plate starts to subduct from the Japan Trench, and the subducted plate is as deep as the mantle transition zone and stalled above the $660-\mathrm{km}$ velocity discontinuity. It can be seen in the images that there are apparent low-velocity anomalies in the upper mantle beneath northeast China. The corresponding mantle transition zone shows high-velocity anomalies (Figures 2, 3). Meanwhile, for the accurate portrayal of the subduction plate morphology, regarding the westward extension distance and thickness of the Pacific slab stagnation, the $\mathrm{P}$-wave imaging models of Wei et al. (2012) and Fukao and Obayashi (2013) showed that the leading edge of the stagnant slab could reach near below Abaga volcano. Li et al. (2013) and Lai et al. (2019) inferred the western boundary of the stagnant Pacific slab to be about $118^{\circ} \mathrm{E}$ (the stagnant slab in the mantle transition zone is about $1,200 \mathrm{~km}$ long and $140 \mathrm{~km}$ thick) by triplicated waveform modeling.

Lei and Zhao (2005) obtained the velocity structure of the upper mantle beneath Changbaishan volcano by processing the data from 19 portable stations and three permanent stations through the seismic body wave traveltime tomography method. The results showed apparent low-velocity anomalies about $10 \mathrm{~km}$ below Changbaishan volcano, and their extension direction corresponds well with Longgang volcano in the west and Xianjingdao volcano in the south. Moreover, these lowvelocity anomalies extend to about $400 \mathrm{~km}$, and high-velocity anomalies appear in the mantle transition zone. They thought that the Western Pacific subduction slab stalled in the mantle transition zone. The deep dehydration process of the plate and the convective circulation process in the big mantle wedge led to the upwelling of high-temperature asthenosphere material. And, the hot upwelling material to about $180 \mathrm{~km}$ was transported upwards from east to west and from north to south respectively, which became the material source of Changbaishan volcano (Figure 4). However, Tang et al. (2014) gained seismic images and triplicated waveform modeling results from the NECESSArray experiment. The result showed a low-velocity anomaly beneath Changbaishan 


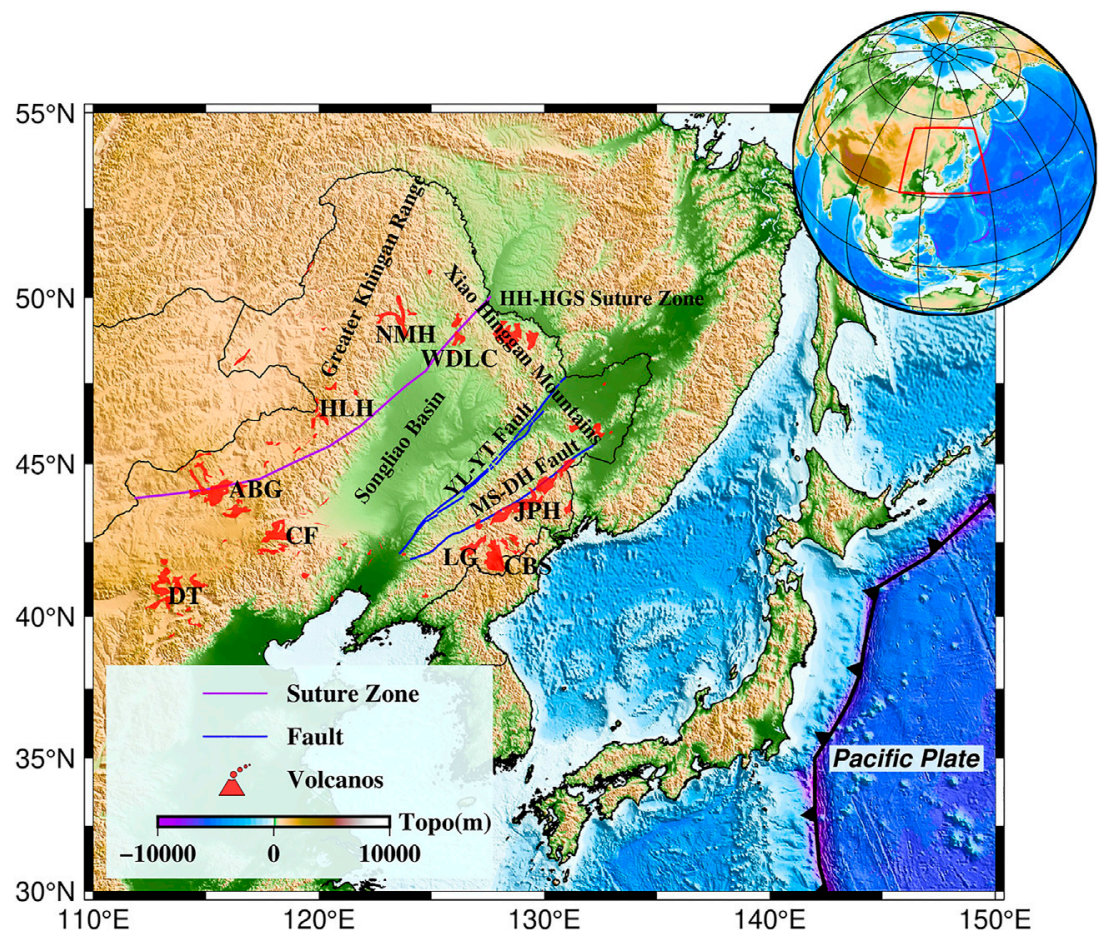

FIGURE 1 | Distribution of Cenozoic volcanoes in northeast China. Red areas represent volcanoes, CBS-Changbaishan volcano; LG-Longgang volcano; JPHJingpohu volcano; WDLC-Wudalianchi volcano; NMH-Nuominhe volcano; HLH -Halaha volcano; ABG - Abaga volcano; CF - Chifeng volcano; DT - Datong volcano. Blue lines indicate major fault, YL-YT Fault: Yilan-Yitong Fault; MS-DH Fault: Mishan-Dunhua Fault. Blue lines indicate major suture.
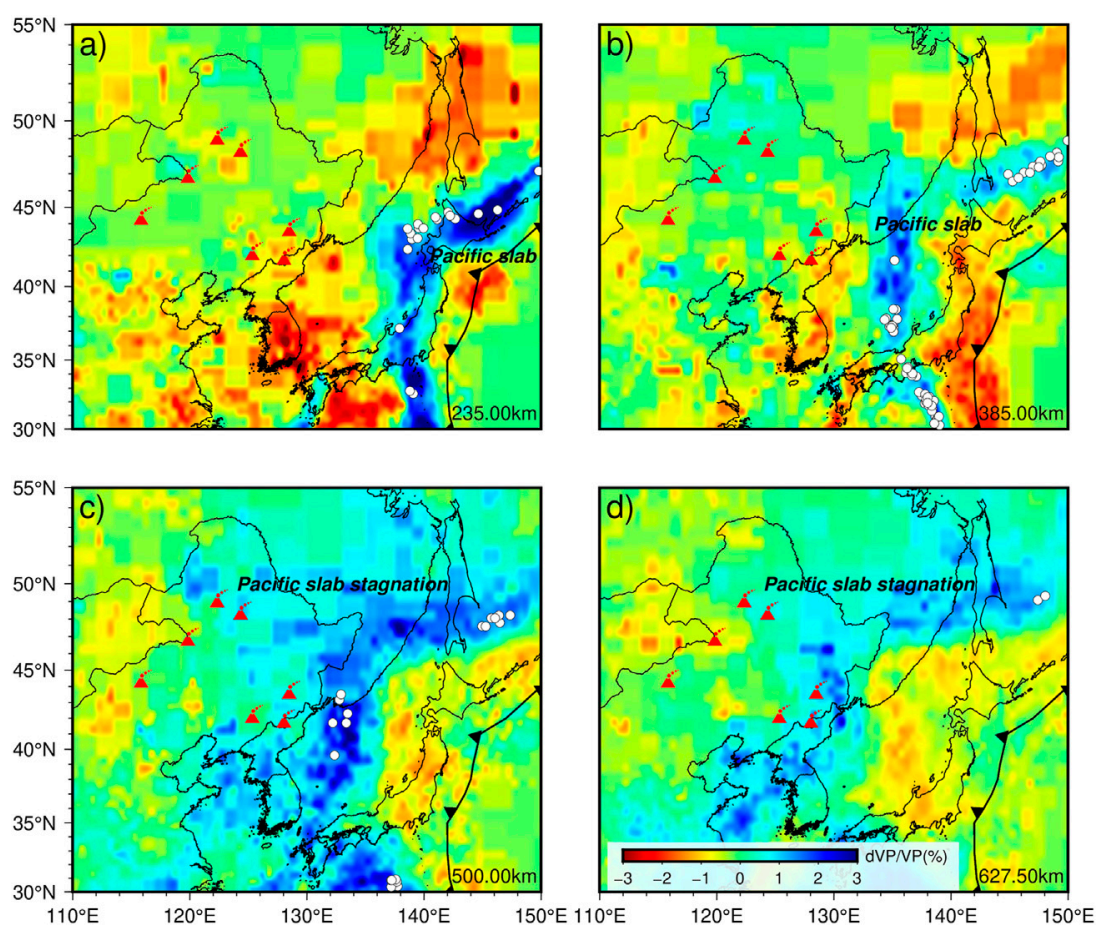

FIGURE 2 | Horizontal depth slices of P-wave velocity perturbation beneath the UU-P07 model in northeast China (Amaru, 2007). Figure (A), (B), (C), and (D) respectively represents the horizontal depth slice of 235.00 km, 385.00 km, 500.00 km, and 627.00 km. Red triangles represent Cenozoic volcanoes. The white circles represent seismic events larger than magnitude 4 that occurred at this depth $( \pm 20 \mathrm{~km})$ during 2019.7-2021.7. 

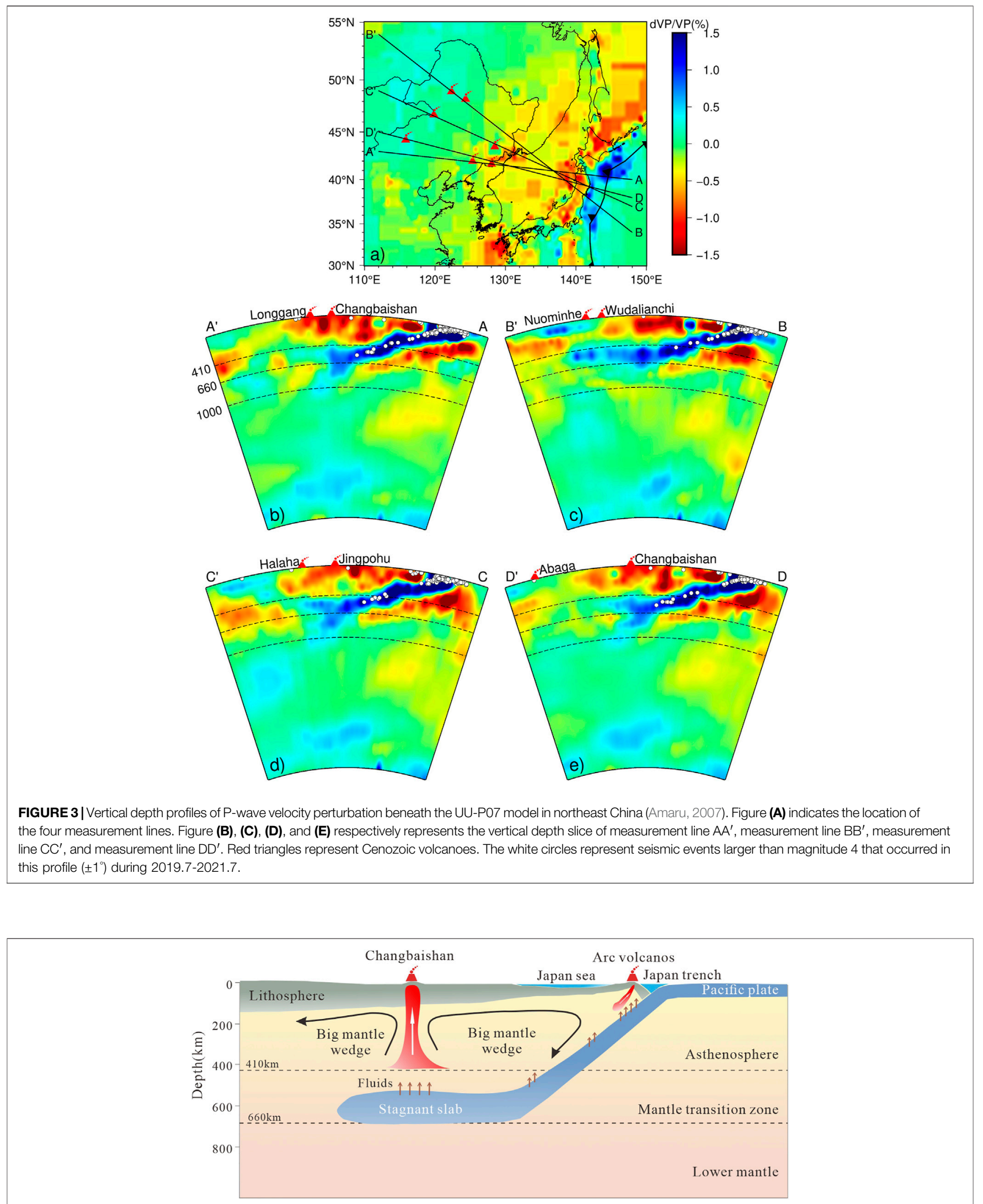

FIGURE 4 | Cartoon diagram of the model of plate dehydration in the large mantle wedge model induced volcanism in northeast China. See text for details. 


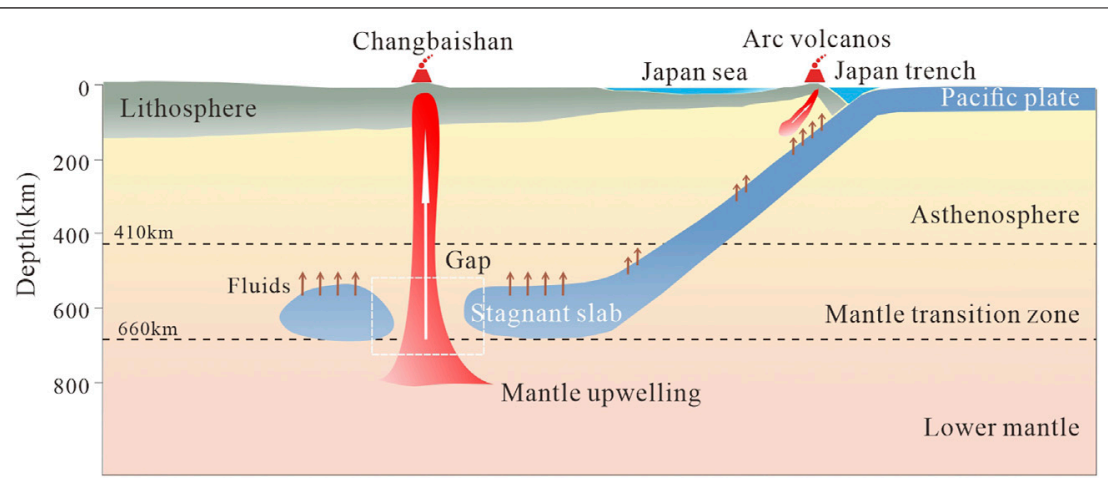

FIGURE 5 | Cartoon diagram of the model of volcanism in northeastern China induced by decompression melting from the upwelling of lower mantle material. See text for details.

volcano that continues below $660 \mathrm{~km}$, with a "gap" in the stagnant Pacific slab in the transition zone. They thought that the volcanic activity of Changbaishan may be caused by the upwelling of the lower mantle material through the "gap" in the stagnant slab and decompression melting in the asthenosphere (Figure 5).

$\mathrm{He}$ and Santosh (2016) discovered the significant traces of mantle upwelling in northeast China through the receiver function and teleseismic P-wave tomography method. They speculated that these observed low-velocity anomalies might be vestiges of a mantle plume. He (2021) used the CCP (common-conversion-point) stacking technique of receiver function to delineate the structure of the upper mantle transition zone in northeast China more finely, and the study found the relics of an upwelling mantle plume beneath the Songliao basin. And combined with the finding of $\mathrm{He}$ et al. (2014) that the projection of the mantle plume at the surface overlies the lithosphere and crustal thinning and the location of the mafic-ultramafic regions, he speculated that the mantle plume triggered the large-scale volcanism in the Mesozoic in northeast China and may have led to the formation of the Songliao Basin. Further analysis revealed that the volcanism in northeast China showed a spatial shift from the center of the Songliao Basin to the basin margin from Mesozoic to Cenozoic. The age of volcanism products decreased from west to east in northeast China (Sun et al., 2020). These indicated that the Mesozoic mantle plume migrated and tilted toward Changbaishan in the southern Songliao Basin during the Mesozoic-Cenozoic. And finally, the mantle plume beneath the Changbaishan triggered the Cenozoic volcanism in northeast China.

The global seismic tomography results show that the Jingpohu volcano and Changbaishan volcano share similar structural features of the upper mantle and mantle transition zone. However, Duan et al. (2009) obtained the P-wave velocity structure beneath Jingpohu volcanic area by using the seismic body wave traveltime tomography method. They found that there is no obvious low-velocity anomaly in the crust, and seems to be a more apparent high-velocity anomaly extending down to the top of the mantle transition zone. Besides, the surface wave imaging results of Fu et al. (2016) and the S-wave imaging results of Fan and Chen (2019) show low-velocity anomalies from the bottom of the crust below Jingpohu volcano to the top of the asthenosphere. Still, no evident low-velocity bodies are found in the crust. These imply that partial melting may exist beneath Jingpohu volcano, but the degree of melting of the lithospheric mantle is lower than that of Changbaishan volcano (Chen et al., 2007).

Wei et al. (2019) gained the P-wave velocity structure beneath the Wudalianchi volcano and Halaha volcano utilizing a teleseismic tomography imaging method on data from two roughly parallel linear north-west oriented seismic arrays in northeast China. The results showed that a low-velocity anomaly with a width of about $80 \mathrm{~km}$ exists beneath the Wudalianchi volcano, which extends vertically from about $35 \mathrm{~km}$ to about $200 \mathrm{~km}$ and further southeast to the top of the mantle transition zone, and an apparent high-velocity anomaly is visible in the mantle transition zone. A low-velocity body extending into the mantle transition zone can be observed below the Halaha volcano, while a high-velocity anomaly is still visible in the mantle transition zone. Comparing global and regional seismic tomography results (Zhao, 2004; Li et al., 2013; Li et al., 2016; Lai et al., 2019), they inferred that the highvelocity anomalies in the mantle transition zone beneath Wudalianchi volcano and Halaha volcano are the Pacific subduction slab, indicating that their genesis is closely related the Pacific subduction slab. They further speculated that the formation of the Wudalianchi volcano is connected with convective circulation in the big mantle wedge above the Pacific stagnant slab. In contrast, the source of the Halacha volcano was supplied by local upwelling caused by the collapse of the stagnant slab into the lower mantle for dehydration (Schmandt et al., 2014).

Guo et al. (2016) acquired the surface wave velocity structure of the crust and upper mantle within $200 \mathrm{~km}$ in northeast China by seismic noise imaging. The results showed that the velocity in the Songliao Basin is relatively high in the upper mantle $50-200 \mathrm{~km}$. Low-velocity anomalies extending up to $200 \mathrm{~km}$ can be seen beneath Changbaishan volcano and Jingpohu volcano on the eastern edge of the Songliao Basin. Lowvelocity anomalies also reach about $200 \mathrm{~km}$ under the Halaha volcano on the western edge of the Songliao Basin. The lowvelocity anomaly beneath the Abaga volcano only extends to 


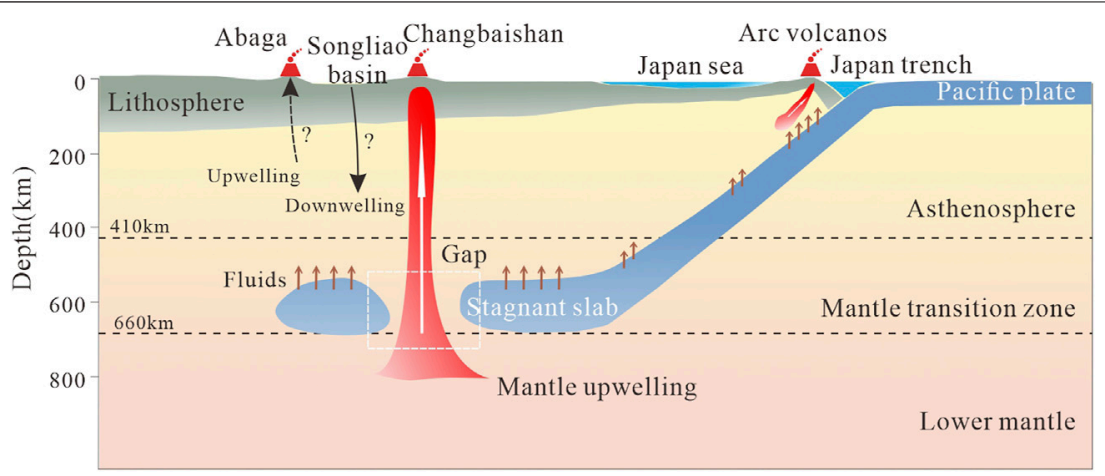

FIGURE 6 | Cartoon diagram of the model of small-scale upper mantle convection induced volcanism in northeast China. See text for details

about $150 \mathrm{~km}$. Based on the observed surface wave velocity structure and the S-wave velocity imaging results, Tang et al. (2014) proposed a small-scale upper mantle convection model to explain the genesis of intraplate volcanoes in northeast China. Among them, the upwelling from the mantle transition zone or deeper mantle below Changbaishan volcano caused local convection in the upper mantle of northeast China: the lowvelocity anomaly in the upper mantle below Changbaishan volcano corresponds to the upward branch of this convective unit, and the high-velocity anomaly in the upper mantle below Songliao Basin corresponds to the downward branch of this convective unit, and the downwelling below Songliao Basin may have induced the secondary local convection in the asthenosphere below the western Greater Khingan Range, and the rising secondary local convection triggered the volcanic activities of Halaha and Abaga (Figure 6).

Fan et al. (2021) used ambient noise and earthquake two-plane wave tomography methods to obtain high-precision threedimensional S-wave velocity structures of the crust and upper mantle in northeast China. The imaging results showed that the top of the upper mantle beneath Changbaishan volcano, Longgang volcano, Jingpohu volcano, Abaga volcano, Halaha volcano exhibits significant low-velocity anomalies, indicating that the upwelling asthenosphere may have reached (or approached) the Moho surface; while, the top of the upper mantle beneath Wudalianchi volcano and Nuominhe volcano exhibits relatively high-velocity anomalies, which may indicate the presence of the lithospheric mantle in the region. Combined with the results of previous petrological and geochemical studies (Foley et al., 1987), they hypothesized that the sodic basalts of a series of volcanoes, including Changbaishan volcano, are mainly from the upwelling asthenosphere mantle, while the high potassium basalts of Wudalianchi and Nuominhe volcanoes are the products of the interaction between the low degree melt of the asthenosphere and the overlying lithospheric mantle. The results of this study reveal that the significant spatial variability in intensity and scale of asthenosphericlithospheric mantle interactions beneath northeast China due to continuous subduction of the western Pacific plate since the late Mesozoic controlled the origin of the Quaternary sodic and potassic intraplate volcanism. Zhang et al. (2021) jointly inverted new surface-wave dispersion data, surface heat flow, geoid height, and elevation data to image the fine-scale thermal and compositional structure of northeast China and inferred partial melt regions of the mantle. It was found that the location and composition of basaltic volcanism correlate well with the anomalous hot asthenosphere regions and the shallow lithosphere-asthenosphere boundary. These results suggest that intraplate volcanism's occurrence, location, and composition are controlled by the interaction of shallow asthenospheric circulation and lithospheric thickness.

Generally speaking, there are three main models for the genesis of intraplate volcanoes in northeast China under different velocity structure backgrounds: 1) the plate dehydration model in the big mantle wedge model, which suggests that there is a horizontal spreading subduction slab in the mantle transition zone with high-velocity anomaly, and the water carried by the subduction slab is released into the large mantle wedge above it, and the mantle wedge material melts under the action of water, leading to volcanic activity. 2) the decompression melting model from the upwelling of material from the lower mantle, which suggests that hot material from deep in the lower mantle is upwelling beneath the volcano through the stagnant slab vacancy created by tearing, and forming a source of volcanic activity by decompression melting. 3) the small-scale upper mantle convection model, which argues that the upwelling of hot material from the mantle transition zone or deeper mantle triggers local convection in the upper mantle, leading to volcanic activity. The latter two models are based on the presence of lowvelocity anomalies at the front end of the high-velocity subduction slab, suggesting that the deep velocity structure is an essential factor constraining the volcano genesis mechanism in northeast China.

\section{ELECTROMAGNETIC IMAGING RESULTS}

Seismic wave velocities are closely related to medium elastic constants, density, and lithology. It can be used to characterize the dynamics of the Earth's interior, such as mantle convection, the evolution of subducted plates, and the origin of continents ( $\mathrm{Li}$ 


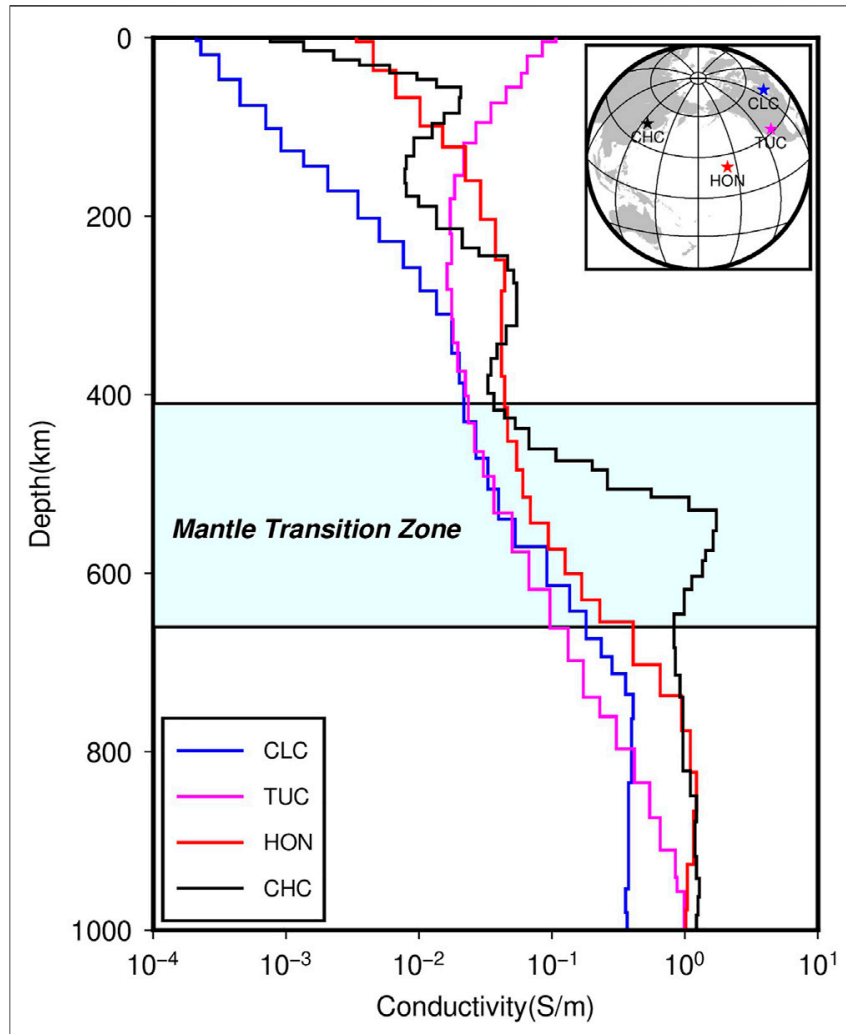

FIGURE 7 | One-dimensional electrical structure of northeast China (CHC) (Ichiki et al., 2001) compared with conductivity models of Carty Lake (CLC) in the Canadian Shield, Tucson (TUC) in the southwestern United States, and Honolulu (HON) region in the north-central Pacific Ocean (Neal et al., 2000)

and van der Hilst, 2010). However, seismic wave velocities are not sensitive to temperature, the presence of water and melt. Instead, the water content of the Earth's interior strongly influences the evolution and dynamics of the Earth, which ultimately controls the occurrence of earthquakes and volcanoes (Munch et al., 2020). Electrical conductivity is a property of rocks that varies with temperature and water content. Therefore, the electrical structure obtained from electromagnetic imaging studies can provide complementary information to seismic imaging results to more fully understand the deep structure of volcanoes.

Ichiki et al. (2001) inferred the conductivity structure of the mantle in northeast China by long-period magnetotelluric and geomagnetic depth sounding experiments. Compared with the conductivity models of Carty Lake (CLC) in the Canadian Shield, Tucson (TUC) in the southwestern United States, and Honolulu (HON) in the north-central Pacific Ocean (Neal et al., 2000) (Figure 7), it was found that the conductivity of the mantle transition zone beneath northeast China is nearly an order of magnitude higher than that of other tectonic environments. It is speculated that this phenomenon is likely related to the presence of water in the stagnant slab. Moreover, the global mantle conductivity models of Kelbert et al. (2009) and Semenov and Kuvshinov (2012) also showed obvious high-conductivity anomalies in the mantle transition zone beneath northeast
China. Similarly, Munch et al. (2020) used a joint probabilistic density inversion of the estimated global-tolocal transfer functions of the ionospheric and magnetospheric electromagnetic signals to obtain the conductivity structure of the upper mantle and mantle transition zone beneath 20 geomagnetic stations, and combined it with the mantle thermochemical structure analyzed from seismic data to gain the mantle water content, which showed that a large amount of water $\left(C_{w}^{w a d} \sim 0.3 w t \%\right)$ exists in the transition zone beneath the North Asian. Combined with the seismic imaging results, it can be speculated that the water carried during the subduction of the western Pacific plate beneath northeast China was released due to changes in temperature and pressure conditions, which strongly influenced the tectonic evolution of northeast China.

At present, many magnetotelluric experiments have been carried out for Cenozoic volcanoes in northeast China. The electrical structures beneath Changbaishan volcano, Jingpohu volcano, Wudalianchi volcano, and Halaha volcano have been obtained. The electromagnetic imaging results of Changbaishan volcano showed an isolated low resistance body in the range of about $10-30 \mathrm{~km}$ with a downward trend beneath the north and east area of Tianchi crater, which is presumed to be a crustal magma capsule formed by magma transported up from below the earth's crust (Tang et al., 2001; Qiu et al., 2014; Ruan et al., 2020). Zhu et al. (2001) conducted magnetotelluric experiments for 30 stations in the Jingpohu volcano. They found that the resistivity of the surrounding area below the volcano is high, and there is a low resistance vertical column with an irregular cross-section elongated in the northeast direction in the middle. The resistivity of this column is not uniform from top to bottom, with medium resistance at the top, high resistance at the middle, and low resistance at the bottom. It is presumed to be a former magma channel, so the resistivity is lower than the surrounding resistivity. When the volcano stopped erupting, the magma cooled, and the resistivity became higher, but it is still much lower than the resistivity on both sides. Zhan et al. (1999) processed seven magnetotelluric profiles of Wudalianchi volcano. The results showed that a rivet-like high resistance anomaly exists at a depth of several hundred meters to about $15-20 \mathrm{~km}$ below the surface, and the high resistance body has been connected to the upper mantle through the crust. Its resistivity gradually decreases with increasing depth, which is presumed to be a magma channel during consolidation. However, no obvious low resistance magma capsule is found in the crust. Tang et al. (2015) observed seven magnetotelluric sites at Halaha volcano. They found an alternating lateral distribution of high and low resistance in the lower and middle crust $(9-30 \mathrm{~km})$. The two low resistance zones are located just below two volcanic zones with the same subsurface magma pathway to the mantle.

Summarizing the results of electromagnetic studies on the individual volcano, it can be found that crustal magma capsules exist in the Changbaishan volcano. Moreover, the crustal magma 


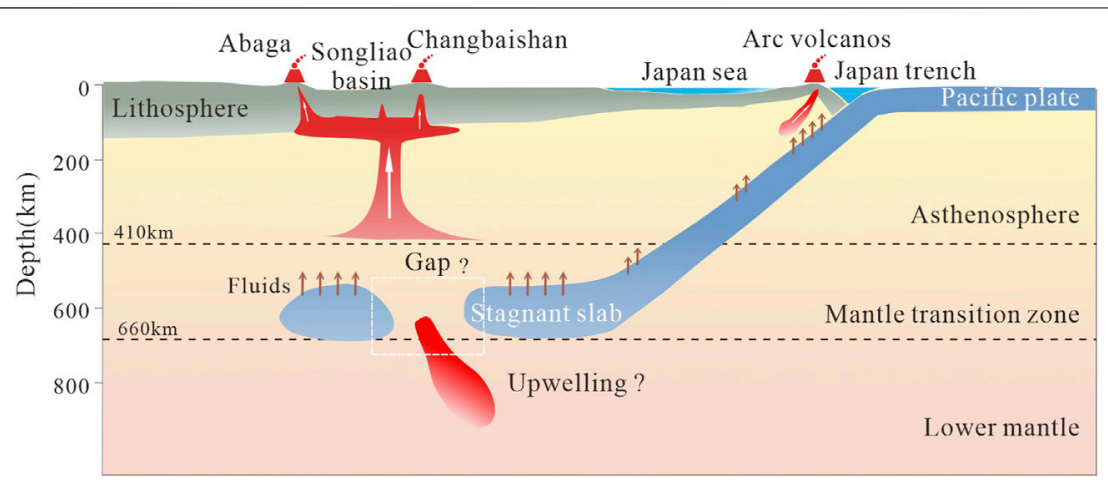

FIGURE 8 | Cartoon diagram of the model of mantle upwelling piercing the lithosphere induced volcanism in northeast China. See text for details.

capsule must directly connect with the deep mantle to ensure sufficient heat source replenishment to maintain the melt. Although no obvious crustal magma capsules are found in other volcanoes in northeast China, they all seem to have magma channels to the deep mantle. In order to explore the connection of volcanoes in northeast China at greater depths and to better understand the genesis of these volcanoes, a longer period of electromagnetic sounding is needed. Li et al. (2020) used long-period array magnetotelluric data to obtain the threedimensional electrical structure of the upper mantle scale in northeast China. The results showed that there were several independent low-resistance anomalies in the lithospheric mantle. With the increase of depth, the scale of these low resistance anomalies became more significant. To the deep part of the upper mantle, the shape of these low resistance anomalies corresponded to the contour of the Songliao Basin. The petrophysical analysis showed that these low resistance anomalies were caused by high water content and partial melt material. We speculate that this is due to the continuous dehydration of the Pacific stagnant plate in the mantle transition zone below northeast China, which causes partial melting at the top of the mantle transition zone below Songliao Basin. The partially molten mantle hot materials were transported upward by buoyancy, melted through the asthenosphere, and bottomed out the bottom of the dry lithosphere. Finally, they pierced the weak tectonic boundary, which triggered the intraplate volcanism in northeast China (Figure 8). Xu et al. (2020) found that the distribution of Cenozoic high-Mg andesites in northeast China corresponds well with the leading edge of the stagnant slab in the mantle transition zone (Zhao et al., 2009), and the magnetotelluric imaging results show that there are obvious low- resistance anomalies in the mantle below the distribution area of high$\mathrm{Mg}$ andesites (Li et al., 2020) by analyzing regional geophysical data. Moreover, geochemical signatures indicate that the high-Mg andesites in northeast China originated from partial melting of water-bearing mantle peridotite. Therefore, they suggest that the formation of high-Mg andesites was facilitated by the abundant recycled ancient sediments and water from the leading edge of the stagnant slab in the mantle transition zone, which provided the material source for the Cenozoic volcanism in northeast China.

\section{DISCUSSION}

During subduction, when the subducting slab reaches a certain depth, it is subjected to the high temperature and pressure of the environment. It undergoes dehydration of rocks due to phase transition, dehydration of hydrated minerals by extrusion, and water production by melting due to friction during subduction. Although most water is released from the oceanic crust at the depth of $150-200 \mathrm{~km}$, in cold subduction environments such as the western Pacific slab, water can also enter the mantle transition zone or even deeper through storing in minerals such as lawsonite and dense hydrous magnesium silicates, or as nominally anhydrous minerals (Zheng et al., 2016).

The spatial resolution of seismic and electromagnetic models is a prerequisite for tectonic interpretations. The UU-P07 model, mentioned in the previous section, can resolve $\mathrm{P}$-wave velocity anomalies with a horizontal variation of $0.4^{\circ}$ in the crust and upper mantle and satisfactorily resolve the stagnant plate morphology in the upper mantle transition zone. The horizontal resolution of the big mantle wedge model proposed by Lei and Zhao (2005) is $2^{\circ} \times 2^{\circ}$, and the resolution is higher in the depth range of $10-400 \mathrm{~km}$ with the vertical grid node spacing is about $200 \mathrm{~km}$. These indicate that the low-velocity anomalies extending to about $400 \mathrm{~km}$ beneath Changbaishan volcano are a reliable feature. Tang et al. (2014) confirmed the existence of the "gap" in the stagnant Pacific slab in the transition zone by examining the horizontally polarized $(\mathrm{SH})$ displacement waveforms propagating through the mantle transition zone anomaly. Guo et al. (2016) performed a horizontal resolution of $2^{\circ} \times 2^{\circ}$ detection plate test and S-wave velocity model constraint within a vertical depth of $300 \mathrm{~km}$ in proposing the small-scale upper mantle convection model. Similarly, Li et al. (2020) performed a resolution test, divided the electromagnetic model using a grid spacing of $30 \mathrm{~km}$, and limited the model depth to $35-350 \mathrm{~km}$ based on the electromagnetic data period. These ensured the ability of the electromagnetic model to identify lowresistance anomalies in the mantle. In addition, most of the other seismic and electromagnetic models mentioned in the paper were also tested for the resolution to ensure the reliability of the anomaly structure. 
The seismic and electromagnetic imaging results show lowvelocity, high-conductivity anomalies associated with the volcanic magma system beneath the volcanoes in northeast China, and some of the low-velocity bodies extend to the top of the mantle transition zone at a depth of $410 \mathrm{~km}$. There are three ways of magma production or mantle melting: 1) local mantle temperature increase (warming melting); 2) local mantle pressure decrease (depressurization melting); and 3) water released during subduction enters the overlying hot mantle peridotite by buoyancy, lowering its solidus temperature and eventually leading to partial melting of the mantle. Thus, the study of seismic wave velocities and electrical structure combined with rheological analysis suggests that the formation of volcanoes in northeast China is closely related to subduction zone structure and fluid action.

Northeast China is located in the eastern part of the Central Asian orogenic belt between the North China Craton and the Siberian plate, which consists of a succession of microcontinents including the Erguna Massif, Xing'an Massif, SongnunZhangguangcai Ling Massif, Jiamusi Massif, and Xingkai Massif (Zhou et al., 2018). Most of these microcontinents formed during the Rodinia supercontinent breakup. During the Paleozoic period, the mutual closure of ocean basins led to the complex collision between microcontinents. During the Mesozoic, the final closure of the Paleo-Asian Ocean transformed the tectonic system of northeast China, which was influenced by the subduction and retreat of the western Pacific Ocean plate, resulting in an overall tensional environment in northeast China, followed by collisional mountain building, extensional collapse, and post-arc extension. During this period, deep and sizeable lithospheric Fault developed in northeast China, such as the Dunhua-Mishan Fault and the YitongYilan Fault (Tang et al., 2015). These suture zones and Faults provided channels for fluid upwelling in the asthenosphere, which eventually triggered volcanic activity in northeast China.

\section{CONCLUSION}

Seismic and electromagnetic imaging results show that the western Pacific subduction slab is stalled in the mantle transition zone beneath volcanoes in northeast China. There

\section{REFERENCES}

Amaru, M. (2007). Global Travel Time Tomography with 3-D Reference Models. PhD Thesis: Utrecht University.

Chen, C., Zhao, D., Tian, Y., Wu, S., Hasegawa, A., Lei, J., et al. (2017). Mantle Transition Zone, Stagnant Slab and Intraplate Volcanism in Northeast Asia. Geophys. J. Int., ggw491. doi:10.1093/gji/ggw491

Chen, Y., Zhang, Y., Graham, D., Su, S., and Deng, J. (2007). Geochemistry of Cenozoic Basalts and Mantle Xenoliths in Northeast China. Lithos 96 (1-2), 108-126. doi:10.1016/j.lithos.2006.09.015

Duan, Y., Zhao, D., Zhang, X., Xia, S., Liu, Z., Wang, F., et al. (2009). Seismic Structure and Origin of Active Intraplate Volcanoes in Northeast Asia. Tectonophysics 470 (3-4), 257-266. doi:10.1016/j.tecto.2009.01.004 are obvious low-velocity and high-conductivity anomalies in the corresponding crust and upper mantle. Rheological analyses suggest that these anomalies are caused by the melt upwelling of deep mantle thermal materials due to the dehydration of the stagnant plate. These hot molten materials eventually punctured the weak tectonic zone of the lithosphere and triggered volcanic activity. This suggests that these volcanoes are back-arc intraplate volcanos and that their genesis is closely linked to the Pacific plate's subduction processes and fluid action.

The accuracy of the velocity and electrical structure beneath volcanoes has important implications for constraints on volcanogenic mechanisms. However, due to differences in observational data and imaging resolution, variations in the physical structure beneath northeast China obtained from different studies result in multiple models remaining for the specific controls used to explain volcano genesis. Therefore, more extensive and fine-scale geophysical imaging work is needed to accurately derive volcanogenic mechanisms in northeast China.

\section{AUTHOR CONTRIBUTIONS}

YD wrote the first draft of the manuscript. $\mathrm{SH}$ and YD contributed to conception and design of the study. XW and ML wrote sections of the manuscript. All authors contributed to manuscript revision, read, and approved the submitted version.

\section{FUNDING}

This work was supported by the National Natural Science Foundation of China under grant 91858214 and the National Key R\&D Program of China under grant 2018YFC0604004.

\section{ACKNOWLEDGMENTS}

All Figures in this study are plotted by the GMT (http://gmt.soest. hawaii.edu/home). Seismic event catalogue downloads from the International Seismological Centre (http://www.isc.ac.uk/ iscbulletin/search/catalogue/).

Fan, X., Chen, Q.-F., Ai, Y., Chen, L., Jiang, M., Wu, Q., et al. (2021). Quaternary Sodic and Potassic Intraplate Volcanism in Northeast China Controlled by the Underlying Heterogeneous Lithospheric Structures. Geology 49 (10), 1260-1264. doi:10.1130/g48932.1

Fan, X., and Chen, Q. F. (2019). Seismic Constraints on the Magmatic System beneath the Changbaishan Volcano: Insight into its Origin and Regional Tectonics. J. Geophys. Res. Solid Earth 124 (2), 2003-2024. doi:10.1029/ 2018jb016288

Foley, S. F., Venturelli, G., Green, D. H., and Toscani, L. (1987). The Ultrapotassic Rocks: Characteristics, Classification, and Constraints for Petrogenetic Models. Earth-Science Rev. 24(2), 81-134. doi:10.1016/0012-8252(87)90001-8

Fu, Y. V., Gao, Y., Li, A., Li, L., Shi, Y., and Zhang, Y. (2016). Origin of Intraplate Volcanism in Northeast China from Love Wave Constraints. J. Geophys. Res. Solid Earth 121 (11), 8099-8112. doi:10.1002/2016jb013305 
Fukao, Y., Obayashi, M., Inoue, H., and Nenbai, M. (1992). Subducting Slabs Stagnant in the Mantle Transition Zone. J. Geophys. Res. 97 (B4), 4809. doi:10.1029/91jb02749

Fukao, Y., and Obayashi, M. (2013). Subducted Slabs Stagnant above, Penetrating through, and Trapped below the $660 \mathrm{Km}$ Discontinuity. J. Geophys. Res. Solid Earth 118 (11), 5920-5938. doi:10.1002/2013jb010466

Guo, Z., Chen, Y. J., Ning, J., Yang, Y., Afonso, J. C., and Tang, Y. (2016). Seismic Evidence of On-Going Sublithosphere Upper Mantle Convection for Intraplate Volcanism in Northeast China. Earth Planet. Sci. Lett. 433, 31-43. doi:10.1016/j.epsl.2015.09.035

He, C., Dong, S., Chen, X., Santosh, M., and Niu, S. (2014). Seismic Evidence for Plume-Induced Rifting in the Songliao Basin of Northeast China. Tectonophysics 627, 171-181. doi:10.1016/j.tecto.2013.07.015

He, C., and Santosh, M. (2016). Seismic Tomographic Evidence for Upwelling Mantle Plume in NE China. Phys. Earth Planet. Interiors 254, 37-45. doi:10.1016/j.pepi.2016.03.007

He, C. (2021). The Structure of the Upper Mantle Transition Zone beneath Northeast China Associated with Mantle Plume Migration. Earth Space Sci. 8 (9). doi:10.1029/2021ea001874

Ichiki, M., Uyeshima, M., Utada, H., Guoze, Z., Ji, T., and Mingzhi, M. (2001). Upper Mantle Conductivity Structure of the Back-Arc Region beneath Northeastern China. Geophys. Res. Lett. 28 (19), 3773-3776. doi:10.1029/ 2001 l012983

Iwamori, H. (1992). Degree of Melting and Source Composition of Cenozoic Basalts in Southwest Japan: Evidence for Mantle Upwelling by Flux Melting. J. Geophys. Res. 97 (B7), 10983. doi:10.1029/92jb00737

Kelbert, A., Schultz, A., and Egbert, G. (2009). Global Electromagnetic Induction Constraints on Transition-Zone Water Content Variations. Nature 460 (7258), 1003-1006. doi:10.1038/nature08257

Lai, Y., Chen, L., Wang, T., and Zhan, Z. (2019). Mantle Transition Zone Structure beneath Northeast Asia from 2-D Triplicated Waveform Modeling: Implication for a Segmented Stagnant Slab. J. Geophys. Res. Solid Earth 124 (2), 1871-1888. doi:10.1029/2018jb016642

Lei, J., and Zhao, D. (2005). P-wave Tomography and Origin of the Changbai Intraplate Volcano in Northeast Asia. Tectonophysics 397 (3-4), 281-295. doi:10.1016/j.tecto.2004.12.009

Li, C., and van der Hilst, R. D. (2010). Structure of the Upper Mantle and Transition Zone beneath Southeast Asia from Traveltime Tomography. J. Geophys. Res. 115. doi:10.1029/2009jb006882

Li, J., Wang, X., Wang, X., and Yuen, D. A. (2013). P and SH Velocity Structure in the Upper Mantle beneath Northeast China: Evidence for a Stagnant Slab in Hydrous Mantle Transition Zone. Earth Planet. Sci. Lett. 367, 71-81. doi:10.1016/j.epsl.2013.02.026

Li, S., Suo, Y., Li, X., Wang, Y., Cao, X., Wang, P., et al. (2018). Mesozoic Plate Subduction in West Pacific and Tectono-Magmatic Response in the East Asian Ocean-Continent Connection Zone. Chin. Sci. Bull. 63 (16), 1550-1593. doi:10.1360/n972017-01113

Li, S., Weng, A., Li, J., Shan, X., Han, J., Tang, Y., et al. (2020). Deep Origin of Cenozoic Volcanoes in Northeast China Revealed by 3-D Electrical Structure. Sci. China Earth Sci. 63 (4), 533-547. doi:10.1007/s11430-018-9537-2

Li, Z., Ni, S., Zhang, B., Bao, F., Zhang, S., Deng, Y., et al. (2016). Shallow Magma Chamber under the Wudalianchi Volcanic Field Unveiled by Seismic Imaging with Dense Array. Geophys. Res. Lett. 43 (10), 4954-4961. doi:10.1002/ 2016GL068895

Liu, X., Zhao, D., Li, S., and Wei, W. (2017). Age of the Subducting Pacific Slab beneath East Asia and its Geodynamic Implications. Earth Planet. Sci. Lett. 464, 166-174. doi:10.1016/j.epsl.2017.02.024

Liu, Y., Niu, F., Chen, M., and Yang, W. (2017). 3-D Crustal and Uppermost Mantle Structure beneath NE China Revealed by Ambient Noise Adjoint Tomography. Earth Planet. Sci. Lett. 461, 20-29. doi:10.1016/j.epsl.2016.12.029

Lu, C., Grand, S. P., Lai, H., and Garnero, E. J. (2019). TX2019slab: A New P and S Tomography Model Incorporating Subducting Slabs. J. Geophys. Res. Solid Earth 124 (11), 11549-11567. doi:10.1029/2019jb017448

Miyashiro, A. (1986). Hot Regions and the Origin of Marginal Basins in the Western Pacific. Tectonophysics 122(3-4), 195-216. doi:10.1016/0040-1951(86) 90145-9

Munch, F. D., Grayver, A. V., Guzavina, M., Kuvshinov, A. V., and Khan, A. (2020). Joint Inversion of Daily and Long-Period Geomagnetic Transfer Functions
Reveals Lateral Variations in Mantle Water Content. Geophys. Res. Lett. 47 (10). doi:10.1029/2020gl087222

Neal, S. L., Mackie, R. L., Larsen, J. C., and Schultz, A. (2000). Variations in the Electrical Conductivity of the Upper Mantle beneath North America and the Pacific Ocean. J. Geophys. Res. 105 (B4), 8229-8242. doi:10.1029/1999jb900447

Qiu, G., Fei, F., Fang, H., et al. (2014). Analysis of Magma Chamber at the Tianchi Volcano Area in Changbai Mountain. Chin. J. Geophys. 57 (10), 3466-3477. (in Chinese). doi:10.6038/cjg20141032

Ruan, S., Tang, J., Dong, Z., Wang, L., Deng, Y., and Han, B. (2020). Electric Structure Model of Tianchi Volcano in Changbai Mountains Based on ThreeDimensional AR-QN Magnetotelluric Inversion. Seismology Geology. 42 (06), 1282-1300. (in Chinese). doi:10.3969/j.issn.0253-4967.2020.06.002

Schmandt, B., Jacobsen, S. D., Becker, T. W., Liu, Z., and Dueker, K. G. (2014). Dehydration Melting at the Top of the Lower Mantle. Science 344 (6189), 1265-1268. doi:10.1126/science. 1253358

Semenov, A., and Kuvshinov, A. (2012). Global 3-D Imaging of Mantle Conductivity Based on Inversion of observatoryC-Responses-II. Data Analysis and Results. Geophys. J. Int. 191 (3), no. doi:10.1111/j.1365246X.2012.05665.X

Sun, M.-D., Xu, Y.-G., Wilde, S. A., Chen, H.-L., and Yang, S.-F. (2015). The Permian Dongfanghong Island-Arc Gabbro of the Wandashan Orogen, NE China: Implications for Paleo-Pacific Subduction. Tectonophysics 659, 122-136. doi:10.1016/j.tecto.2015.07.034

Sun, M., Gao, S. S., Liu, K. H., and Fu, X. (2020). Upper Mantle and Mantle Transition Zone thermal and Water Content Anomalies beneath NE Asia: Constraints from Receiver Function Imaging of the 410 and $660 \mathrm{Km}$ Discontinuities. Earth Planet. Sci. Lett. 532, 116040. doi:10.1016/ j.epsl.2019.116040

Tang, J., Deng, Q., Zhao, G., Li, W., Xuan, F., Jin, W., et al. (2001). Electric Conductivity and Magma Chamber at the Tianchi Volcano Area in Changbaishan Mountain. Seismology Geology. 23 (2), 191-200. (in Chinese).

Tang, J., Xu, W.-L., Wang, F., Zhao, S., and Li, Y. (2015). Geochronology, Geochemistry, and Deformation History of Late Jurassic-Early Cretaceous Intrusive Rocks in the Erguna Massif, NE China: Constraints on the Late Mesozoic Tectonic Evolution of the Mongol-Okhotsk Orogenic belt. Tectonophysics 658, 91-110. doi:10.1016/j.tecto.2015.07.012

Tang, Y., Obayashi, M., Niu, F., Grand, S. P., Chen, Y. J., Kawakatsu, H., et al. (2014). Changbaishan Volcanism in Northeast China Linked to SubductionInduced Mantle Upwelling. Nat. Geosci 7 (6), 470-475. doi:10.1038/ngeo2166

Tatsumi, Y., and Eggins, S. (1995). Subduction Zone Magmatism. London: Blackwell Science, 211

Tatsumi, Y., Maruyama, S., and Nohda, S. (1990). Mechanism of Backarc Opening in the Japan Sea - Role of Asthenospheric Injection. Tectonophysics 181(1-4), 299-306. doi:10.1016/0040-1951(90)90023-2

Turcotte, D., and Schubert, G. (1982). Geodynamics. New York: Wiley.

Wei, W., Hammond, J. O. S., Zhao, D., Xu, J., Liu, Q., and Gu, Y. (2019). Seismic Evidence for a Mantle Transition Zone Origin of the Wudalianchi and Halaha Volcanoes in Northeast China. Geochem. Geophys. Geosyst. 20 (1), 398-416. doi:10.1029/2018gc007663

Wei, W., Xu, J., Zhao, D., and Shi, Y. (2012). East Asia Mantle Tomography: New Insight into Plate Subduction and Intraplate Volcanism. J. Asian Earth Sci. 60, 88-103. doi:10.1016/j.jseaes.2012.08.001

Xu, W.-L., Chen, J.-H., Weng, A.-H., Tang, J., Wang, F., Wang, C.-G., et al. (2020). Stagnant Slab Front within the Mantle Transition Zone Controls the Formation of Cenozoic Intracontinental High-Mg Andesites in Northeast Asia. Geology 49 (1), 19-24. doi:10.1130/g47917.1

Yang, J., and Faccenda, M. (2020). Intraplate Volcanism Originating from Upwelling Hydrous Mantle Transition Zone. Nature 579 (7797), 88-91. doi:10.1038/s41586-020-2045-y

Zhan, Y., Zhao, G., Bai, D., Jin, W., Wang, X., et al. (1999). Preliminary Study of Wudalianchi Volcanic Cluster in Heilongjiang Province by MT Measurement. Geol. Rev. (in Chinese) 45 (S1), 400-408. doi:10.16509/j.georeview.1999.s1.049

Zhang, A., Guo, Z., Afonso, J. C., Handley, H., Dai, H., Yang, Y., et al. (2021). Lithosphere-asthenosphere Interactions beneath Northeast China and the Origin of its Intraplate Volcanism. Geology. doi:10.1130/g49375.1

Zhao, D. (2004). Global Tomographic Images of Mantle Plumes and Subducting Slabs: Insight into Deep Earth Dynamics. Phys. Earth Planet. Interiors 146 (1-2), 3-34. doi:10.1016/j.pepi.2003.07.032 
Zhao, D. (2021). Seismic Imaging of Northwest Pacific and East Asia: New Insight into Volcanism, Seismogenesis and Geodynamics. Earth-Science Rev. 214, 103507. doi:10.1016/j.earscirev.2021.103507

Zhao, D., Tian, Y., Lei, J., Liu, L., and Zheng, S. (2009). Seismic Image and Origin of the Changbai Intraplate Volcano in East Asia: Role of Big Mantle Wedge above the Stagnant Pacific Slab. Phys. Earth Planet. Interiors 173 (3-4), 197-206. doi:10.1016/ j.pepi.2008.11.009

Zhao, D., Yu, S., and Ohtani, E. (2011). East Asia: Seismotectonics, Magmatism and Mantle Dynamics. J. Asian Earth Sci. 40 (3), 689-709. doi:10.1016/j.jseaes.2010.11.013

Zheng, Y., Chen, R., Xu, Z., and Zhang, S. (2016). The Transport of Water in Subduction Zones. Sci. China Earth Sci. 59 (4), 651-682. doi:10.1007/s11430-015-5258-4

Zhou, J.-B., and Li, L. (2017). The Mesozoic Accretionary Complex in Northeast China: Evidence for the Accretion History of Paleo-Pacific Subduction. J. Asian Earth Sci. 145, 91-100. doi:10.1016/j.jseaes.2017.04.013

Zhou, J.-B., Wilde, S. A., Zhao, G.-C., and Han, J. (2018). Nature and Assembly of Microcontinental Blocks within the Paleo-Asian Ocean. Earth-Science Rev. 186, 76-93. doi:10.1016/j.earscirev.2017.01.012

Zhu, R., Fu, W., Meng, L., Chen, H., and Zhao, Y. (2001). Preliminary Study of Electric Structure in the Jingpohu Volcano Area of the Heilongjiang Province.
Seismology Geology. (in Chinese) 23 (2), 186-190. CNKI:SUN:DZDZ.0.200102-008.

Conflict of Interest: The authors declare that the research was conducted in the absence of any commercial or financial relationships that could be construed as a potential conflict of interest.

Publisher's Note: All claims expressed in this article are solely those of the authors and do not necessarily represent those of their affiliated organizations, or those of the publisher, the editors and the reviewers. Any product that may be evaluated in this article, orclaim that may be made by its manufacturer, is not guaranteed or endorsed by the publisher.

Copyright $\odot 2022$ Deng, Huang, Wu and Li. This is an open-access article distributed under the terms of the Creative Commons Attribution License (CC BY). The use, distribution or reproduction in other forums is permitted, provided the original author(s) and the copyright owner(s) are credited and that the original publication in this journal is cited, in accordance with accepted academic practice. No use, distribution or reproduction is permitted which does not comply with these terms. 